\section{On the Pupation of the Nymphalidæ}

In NATURE, vol. xvi. p. 502, I called attention to soine observations and experiments of mine on the pupation of several species of Nymphalida and Pierida, the results of which were: (I) That, in the species referred to, a connection (larvo-pupal ligament) exists between the larva-skin and the chrysalis which is the sole support of the suspensus chrysalis during the final process of pupation, namely, during the extraction of its tail from the larval skin and fastening the anal hooks in the sup. porting silk; (2) That this ligament is not confined to the Suspensi, but exists also in species of the Succincti where it has not the same function to perform; and (3) That nevertheless, in these latter cases, when other support is withdrawn by cutting the girdle before pupation, this ligament is capable, in the majority of cases, of fulfilling the same office as it does in the Suspensi.

These views have recently received important confirmation and extension at the hands of Mr. W. H. Edwards, of West Vir. ginia. I refer in the first place to a paper of his in the Canadian Entomologist for December, 1878, which is reprinted in the Entomological Monthly Magazine for the present month. Here Mr. Edwards describes the ligament as found by him in Grapta interrogationis and Danais archippus. In the latter it is black. Of the former Mr. Edwards writes: "When I lifted the flap of skin entirely clear of the struggling segments, and cut it off a little below the tail, the bendings and contortions were not interrupted by my interference, nor was the effort to reach the silk in the least abated. Held firm by the stretched ligament, which was in plain view, the body rose, and the tail, which had got well outside the padded skin and was, before complete extrication, bent backward, now bent forward, and by the upward swing, was brought exactly to the silk. Several times as I was lifting, the skin and chrysalis together were dislodged, and fell into my hand. Then by drawing the skin back the ligament was exposed, and it was distinctly seen that it was attached to the chrysalis by the pointed ends of the ridges before mentioned and that there was no other connection between skin and chrysalis." As regards the second and third points mentioned above, Mr. Edwards writes to me as follows:- "I experimented on Papilio ajax and $P$. asterias, also following your illustration with $P$ ieris, and was successful in discovering the membrane in both species. Ajax has the terminat part of the chrysalis remarkably short, but although I cut the band and let the larva hang, the chrysalis generally succeeded in reaching the button of silk. So with Asterias, in which the terminal joint is longer. I have no doubt all the Papilionidx possess this membrane, and probably the Satyridæ."

We have now the existence of the ligament demonstrated in three species of Suspensi, viz., V. urtica, G. interrogationis, and $D$. arclippus; and in three or four Succincti, namely, Pieris brassica, Papilio ajax, and $P$. asterias, and probably also in $A$. cardamines; all of which latter also pupate more or less successfully when artificially converted into suspensi by cutting the loop. To the case of $A$. cardamines, which, when pupating as an artificial suspensus, does not remove the tail of the chrysalis from the pocket of the old larva skin, there is a parallel in Pyrarga egeria, and perhaps also in Epinephele janira, in regard to the former of which Mr. Newman states ("British Butterflies," p. 85):-“"The skin of the caterpillar always remains attached to the anal extremity [of the chrysalis], even after the butterfly has escaped." In reference to Fanira he writes (op. cit., p. 92):- "Three of my specimens changed to chrysalids," \&c.; "in two instances the skin of the caterpillar remained, enveloping the anal extremity, so that the chrysalis could not be suspended; in the third it hung for a time from a blade of grass, the skin still enveloping the anal extremity, but attached by its anal hooks to silken threads on the grass."

Mr. Edwards promises further researches during the coming season, for which he has favourable opportunities in his locality, and I think we may confidently look for interesting and perhaps important results. The question of rank in the diurnal lepidoptera is one that has been much contested (see Wallace's essay on "The Malayan Papilionidae," \&c., "Contributions to the Theory of Natural Selection," p. 133), and will probably be decided differently, according to the standard of perfection set up; but the question of derivation is probably more capable of definite solution, and on this point the suspensory ligament seems well calculated to afford important guidance. In the meantime more extensive observations and experiments are wanted, and will no doubt be afforded by those interested in the subject when their attention has been once directed to the matter.

Milford, Letterkenny, March 26

J. A. OsBorne

\section{Tides at Chepstow}

I AM unable to find any certain record of "exceptionally high tides" at Chepstow. They must be of rarer occurrence than is commonly supposed. A very high one is mentioned as having flooded the lowest parts of the town January 29, 1846; and a very low neap tide is noted in a wharfinger's boolis, on March 19, 1876. Measurements of these cannot be obtained; but the highest known rise of the tide at Chepstow since the erection of the iron passenger bridge in 1816 , has not exceeded fifty feet; and probably has never attained such an elevation even with the conjunction of much fresh water inland, and a stiff S.S.W. breeze.

Fair proof of the accuracy of this statement is afforded in the elevation of the rallway bridge that spans the $W$ ye about two miles and a half from its mouth. By the requirements of the Admiralty, a clear headway of fifty feet had to be left above the highest known tide. Besides attention to these requirements, the contractors had to provide approaches to the roadway of the bridge, involving, on the Gloucestershire side, a long and deep cutting through limestone rock, and on the Monmouthshire side a lofty embankment. A very large outlay of money depended on the determination of the "highest known tide," for it regulated the point of suspension for the bridge, and the leviel of the approaches. Yet, as may be seen in the official report appended to these notes, forty-four feet only were allowed for the "rise of the tide." The readers of NATURE may refer for a drawing of the bridge, plans, and a detailed report, to the Illustrated London Newe of July 24, 1852, to satisfy themselves.

Through the kindness of Mr. Henry Gillam, and of Messrs. Miller, the lessees of the salmon fisheries in the Severn and in the Wye, I have received mea: urements of this day's tidal range in both rivers, taken personally by those gentlemen. Amongs well-known points I cite the height at Portskewitt landing stage, New Passage, on the Severn, 39 feet 3 inches; at Chepstow railway bridge, 39 feet; at Chepstow Passenger bridge, about a quarter of a mile higher up the river, 35 feet.

In the gengraphical part of Knight's Cyclopædia, article "Chepstow," the rise of water at Chepstow Bridge at high tide is given as "fifty feet, being the greatest tidal rise in Europe."

The highest reliable measurements that $I$ have met with for the tidal rise in the Severn are 47 feet 6 inches, marked on the Portskewitt landing-stage.

For accidental phenomena affecting the tidal levels, I refer to the following extract from the Bristol Tide Book:-

By a careful comparison of the differences of the predicted and observed heights of tide at Bristol with the contemporaneous heights of the barometer, Mr. Bunt found that a depression of one inch in the mercurial column is accompanied by an elevation of fourteen inches, nearly, in the height of the tide. Hence, by observing the state of the barometer a few hours before high water, we obtain the following correction of the height predicted in the tide table :-

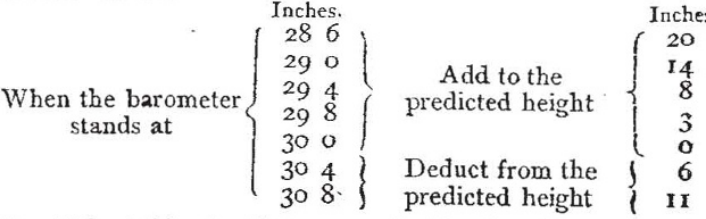

Our highest tides for 1879 are marked in the table as occurring Monday, March Io, and Tuesday, April 8. JUHN YeATS Chepstow, March 24

P.S.-Through the kindness of the four brothers Miller, I am this morning in possession of measurements of yesterday's tide in the Severn and Wye, taken, by the request of the firm, at distant stations. I nclose one, at Tintern Abbey, taken by Wm. Bowen, a regular correspondent of the Meteorological Department.

March 25

Tintern Abbey, near Chepstow, March 24 Mr. Alexander Miller

DEAR SIR,-As requested, I have taken the height of the flow of tide this morning and find it 15 feet $\mathbf{I}$ inch above present level 